This item was submitted to Loughborough's Research Repository by the author.

Items in Figshare are protected by copyright, with all rights reserved, unless otherwise indicated.

\title{
Book Review: Border Work. Spatial lives of the state in Rural Central Asia
}

PLEASE CITE THE PUBLISHED VERSION

http://dx.doi.org/10.1080/09668136.2015.1020040

\section{PUBLISHER}

(c) Taylor \& Francis

\section{VERSION}

AM (Accepted Manuscript)

\section{PUBLISHER STATEMENT}

This work is made available according to the conditions of the Creative Commons Attribution-NonCommercialNoDerivatives 4.0 International (CC BY-NC-ND 4.0) licence. Full details of this licence are available at: https://creativecommons.org/licenses/by-nc-nd/4.0/

\section{LICENCE}

CC BY-NC-ND 4.0

\section{REPOSITORY RECORD}

Pfoser, Alena. 2019. "Book Review: Border Work. Spatial Lives of the State in Rural Central Asia”. figshare. https://hdl.handle.net/2134/19106. 


\section{Review of}

Reeves, Madeleine, Border Work. Spatial Lives of the State in Rural Central Asia. New York NY: Cornell University Press, 2014, xiv + 292pp., \$29.95 p/b.

Alena Pfoser, Loughborough University

Pre-print manuscript. Published in: Europe-Asia Studies 67.3 (2015): 493-494.

Madeleine Reeves' Border Work is an impressive study of the making of state borders and the labour it involves. Based on several years of fieldwork in the Ferghana Valley, Reeves' ethnography explores the territorialisation of the state in rural Central Asia in the second decade after the fall of socialism, highlighting the conflicts and contradictions that this process generated. This borderland is a highly complex area to study — it is ethnically diverse, borders are not linear but resemble a 'chessboard' with multiple enclaves; they are only partially demarcated, and border guards can shift locations and appear in unexpected places. Reeves guides the reader through the region's political, social and geographical terrain and at the same time uses her ethnography as a starting point to explore a number of theoretical questions: what are borders and how are they made and unmade in particular settings and practices? How does state authority become a domain separate from society-and border guards become personifications of the state? As the title indicates, the book does not take borders for granted; following newer scholarship in the field of border studies, the making of territorially integral states itself is the object of ethnographic inquiry. The book is structured thematically; each chapter highlights a different dimension of border work. Chapter 1 introduces the reader to the fieldwork site in the Batken zone, an irrigation-dependent area in Kyrgyzstan which borders Tajikistan and Uzbekistan. The discussion draws upon works in border studies, the social study of science and cultural geography to theorise the border not as a singular object, but as 'border multiple' (p. 53) which appears in different locations and objects.

Chapter 2 examines state-level interventions and focuses on the history of attempts to 'fix' borders over the past 150 years. It traces the rise of a Westphalian conception of territory during the Soviet period in which ethnic boundaries matched linear territorial borders, which was undermined in practice however, by cross-border land cultivation. Reeves demonstrates how the 'ethno-spatial fixing' that emerged during the Soviet past continues to inform accounts by international and domestic actors, who construct spatial complexity as a problem.

The following two chapters focus on connections and ruptures in the borderland from the perspective of the local population. Chapter 3 examines larger geographical changes from the borderland's integration into Soviet space to present difficulties in border-crossing and status loss in 
Russia, turning Soviet citizens who traded apricots into (illegal) migrants in the construction sector. Chapter 4 looks at border dynamics up close and, using the example of cross-border trade and attempts to transport a dead body for burial across the border, analyses borders as sites of differentiated mobility and enclosure. Reeves illustrates how border-crossing citizens participate in border work, contest attempts to monopolise legitimate movements and use the border to make moral claims.

Chapter 5-which along with Chapter 4, constitutes the most original part of the book-turns to the border guards and contestations over who embodies the state in the borderland. Border guarding in the area is an activity of uncertainty and negotiation as border guards are regularly challenged by people who claim higher political or economic power and demand to pass unchecked. Analysing struggles over authoritisation, Reeves illustrates insightfully that there is no deficit of statehood in Central Asia's borderlands and that the problem rather lies in the multiple assertions of state authority and the difficulty of establishing a clear separation between society and state. While the book focuses largely on ordinary instances of border making, the final chapter analyses the 'eventfulness of borders' (p. 237) through a 'hot' border incident around the Sokh enclave that led to demands over border fortification.

Overall, the book is a wide-reaching study of state spatialisation that makes an important contribution to the study of the region - through its focus on rural areas and its detailed examination of the making of states in Central Asia-and to the study of borders in general. It is particularly strong in its nuanced analysis of the processual and multiple constitutions of borders using a diverse number of sources, including ethnographic observations, statistical data, journalistic and NGO reports and interviews with officials. Focusing on instances where the border is contested and its location is unclear, the ethnography sheds light on the effort it takes to make borders appear coherent and natural and destabilises the commonsensical understanding of statehood as something given. What makes this book particularly interesting and distinct from other studies on border regions is that it brings the study of borders and borderlands into a conversation with the anthropology of the state. Rather than focusing solely on borderland populations and their identities, the book puts the state's spatiality under scrutiny and focuses on how the state is invoked, undermined and enacted in ordinary and extraordinary encounters. In doing so, it goes beyond accounts that see 'state' and 'society' as already constituted and border guards as naturally enacting the state, to analyse the production of the state as a separate and territorial delimited domain, a process that in much scholarship is left unexamined. The book also has important political implications. In examining different conceptualisations of space, Reeves questions the widespread vision that spatial complexity in Central Asia itself generates conflicts and demonstrates that the 
securitisation of borders not only forecloses existing cross-border conviviality but also ethnicises local antagonisms and thus to an extent constitutes the conflicts it aims to resolve. The book is extremely well researched and beautifully, if at times densely, written and deserves to be read by a wide audience. While particularly in comparison to linear and often highly securitised borders in the West, the 'chessboard' borders in the book may appear exceptional, Reeves is able to turn the Kyrgyz-Tajik-Uzbek borderland into a site full of insights that should be of interest not only for area specialists, scholars of post-socialism and policy makers but also for a theoretically versed audience interested in the complex character of borders and states in the twenty-first century. 